This document was prepared in conjunction with work accomplished under Contract No. DE-AC09-96SR18500 with the U. S. Department of Energy.

\title{
DISCLAIMER
}

This report was prepared as an account of work sponsored by an agency of the United States Government. Neither the United States Government nor any agency thereof, nor any of their employees, makes any warranty, express or implied, or assumes any legal liability or responsibility for the accuracy, completeness, or usefulness of any information, apparatus, product or process disclosed, or represents that its use would not infringe privately owned rights. Reference herein to any specific commercial product, process or service by trade name, trademark, manufacturer, or otherwise does not necessarily constitute or imply its endorsement, recommendation, or favoring by the United States Government or any agency thereof. The views and opinions of authors expressed herein do not necessarily state or reflect those of the United States Government or any agency thereof.

This report has been reproduced directly from the best available copy.

Available for sale to the public, in paper, from: U.S. Department of Commerce, National Technical Information Service, 5285 Port Royal Road, Springfield, VA 22161, phone: (800) 553-6847, fax: (703) 605-6900

email: orders@ntis.fedworld.gov

online ordering: http://www.ntis.gov/help/index.asp

Available electronically at http://www.osti.gov/bridge

Available for a processing fee to U.S. Department of Energy and its contractors, in paper, from: U.S. Department of Energy, Office of Scientific and Technical Information, P.O. Box 62, Oak Ridge, TN 37831-0062,

phone: (865)576-8401,

fax: (865)576-5728

email: $\underline{\text { reports@ adonis.osti.gov }}$ 
WSRC-TR-2004-00168

Revision No. 0

Page 1 of 6

Keywords: F-Canyon,

Deactivation, Waste

Characterization,

Process Changes

Retention: Permanent

\section{The Impact of De-inventory and Deactivation on the Characterization of F-Canyon Solid Low Level Waste}

March 25, 2004

Author

Steve Wilson, CBU Environmental Project Support

\section{Classification:}

\section{Unclassified}

Does not Contain

Unclassified Controlled

Nuclear Information

Westinghouse Savannah River Company

Savannah River Site

Aiken, SC 29808 
WSRC-TR-2004-00168

Revision No. 0

Page 2 of 6

\section{SUMMARY}

The process continues to contain similar streams during the Suspension and Deactivation as was in place during normal operations. No new Solid Waste Characterization Plan is needed at this time. The Characterization Plan will require updating per the normal review cycle in 2005. This plan will include an update of the process streams with a decay of isotopes based on the additional two years of activity.

The Cognizant Technical Function (CTF) will continue to monitor process changes monthly to determine if there is an impact on the Waste Characterization. This monitoring will verify that there will be no future changes that will impact the characterization.

This completes the first Action Item on the Problem Identification Report (PIR), 2003-PIR26-0051, Reference No. 1.

\section{BACKGROUND}

The F-Canyon Facility was constructed in the early 1950's for the separation and recovery of ${ }^{239} \mathrm{Pu},{ }^{237} \mathrm{~Np}$ and ${ }^{238} \mathrm{U}$ from irradiated natural or depleted uranium targets and fuel rods using the Purex (Plutonium - Uranium Extraction) process. In the Purex process, the irradiated target or fuel slugs are received from the reactor areas or the Receiving Basin for Offsite Fuels, charged to the dissolvers and dissolved in nitric acid. The resulting solution contains primarily uranium-238 and smaller amounts of plutonium, uranium-235, and fission products. The primary operations conducted in F-Canyon include the separation and recovery of $\mathrm{Pu}-239$ and $\mathrm{U}-238$ from irradiated materials in the stabilization of plutonium residues.

Since 1995, the F-Canyon Complex has been operating to stabilize "at risk" nuclear materials and spent fuel from throughout the DOE complex. That mission is complete and no additional materials requiring the F-Canyon PUREX have been identified. In 2002, the FCanyon facility finished processing Pu Scrap materials such as Rocky Flats Scrub Alloy, miscellaneous metals and EBR II/Mk 42 solution. WSRC has been directed by the Department of Energy to suspend F-Canyon/FB-Line PUREX operation indefinitely.

Since the last Low Level Waste Characterization, Reference No. 2, the F-Canyon has been implementing the PUREX Operations Suspension Plan, Reference No. 4, and the Deactivation Project Plan, Reference No. 5. 
WSRC-TR-2004-00168

Revision No. 0

Page 3 of 6

\section{INTRODUCTION}

F-Canyon submitted a revised characterization plan (Reference No.2) on Sept 10, 2003, documenting the normal radioactive decay and to account for the completion of the Rocky Flats Scrub Alloy (RFSA) campaign. The RFSA campaign was expected to have higher amounts of ${ }^{241} \mathrm{Am}$ than had previously been processed through F-Canyon. Because of this, a bounding ${ }^{241} \mathrm{Am}$ value was assigned to the waste stream (Reference No. 3). Reference No. 2 removed this conservatism once the campaign was completed. The campaign ended April 2002. Reducing the ${ }^{241} \mathrm{Am}$ and normalizing the radiological distribution resulted in increasing the percentages of the other radionuclides in the distribution, including those of interest to Solid Waste Infrastructure (SWI). SWI questioned the accuracy of the characterization of waste shipped between the ending of the campaign April 2002 and the approval of the characterization plan on Sept. 10, 2003 (Reference No. 2). It was determined that most if not all Am-241 was removed from the process as of May 2003. As a result of this, a Problem Identification Report (PIR) was issued to 221-F/Closure Business Unit on November 17, 2003. PIR 2003-PIR-26-0051, "Process Changes not Evaluated per WAC 2.02", Reference No. 1. This PIR stated that there was a "Failure to recognize that the process change would result in a waste characterization change".

Waste shipments were suspended until a review of the previously shipped waste was completed and analyzed. The review of previously shipped waste (applying the distribution from Reference No. 2) confirmed that no Treatment, Storage or Disposal Facility limits were exceeded (Reference No. 1). The characterization forms (WCF) were revised to reflect the process change date as the effective date for the waste stream. The forms were reviewed and approved by SWI.

Shipments were allowed to resume. However, follow-on questions were raised.

(1) How to ensure that future process changes would be evaluated on a timely basis?

(2) What impact (if any) would deactivation have on the radiological distribution of the solid waste?

To address the first question, a tickler was established which requires the Cognizant Technical Function (CTF) to monitor process changes on a monthly basis and make changes to the characterization plan and distribution as appropriate.

The purpose of this document is to address the second question and to determine if the monthly monitoring can be eliminated or the frequency reduced. 
WSRC-TR-2004-00168

Revision No. 0

Page 4 of 6

\section{ANALYSIS}

Interviews were conducted with the GCO and Technical Support Engineer/CTF. Also a review of documents was conducted which included the last two Waste Characterization Plans, Reference Nos. 2 and 3, the PUREX Operations Suspension Plan, Reference No. 4, Deactivation Project Plan, Reference No. 5 and the Deactivation End Points Document, Reference No. 6.

It has been determined that no new streams have been introduced to the F-Canyon Facility since the completion of the last Waste Characterization Plan, Reference No. 7. During the of the Suspension and Deactivation phases, the process has continued to be operated with similar feeds and methods of processing. The flushing of vessels during the deactivation of the facility did not necessitate any introduction of new streams into any part of the process. Flushing either continued through the normal process flow paths or was sent to the tank farm. Contaminated streams were not transferred to a part of the process that would change the existing characterization for the process. The detailed methodology of the deactivation process is found in Reference Nos. 4 and 5.

The quantity of radioactivity in the facility will be greatly reduced during the deactivation process. This flushing process should not significantly change the relative isotopic composition. At this time, the primary contribution of solid waste contamination will be from residual contamination in the process instead of the process fluids. To ensure that this is the case, monthly monitoring of deactivation on the waste streams will continue. As the activity in the waste containers is decreased, waste characterization/CTF will determine if the curie quantification method needs to be changed from dose-to-curie to another approach.

All streams will be maintained at this time. During deactivation, there may be additional solid waste generated due to the related activities. Following deactivation, minimal waste will be generated from the inactive areas. 
WSRC-TR-2004-00168

Revision No. 0

Page 5 of 6

\section{RESULTS AND CONCLUSIONS}

Because the process continues to contain similar streams during Suspension and Deactivation, no new Solid Waste Characterization Plan is needed at this time. The Characterization Plan will require updating per the normal review cycle in 2005 . This plan will include a review of the process streams and a decay of isotopes based on the additional two years of activity.

It is the conclusion of this review that the CTFs will continue to monitor the process for significant changes to the stream composition. 
WSRC-TR-2004-00168

Revision No. 0

Page 6 of 6

\section{REFERENCES}

1. 2003-PIR-26-0051, "Process Changes not Evaluated per WAC 2.02”, N. S. Roddy, Nov. 19, 2003.

2. C-ESR-F-00012, "F-Canyon and Outside Facilities Low Level Waste Characterization Plan", J. C. Nims, Sept. 10, 2003, Rev. No. 3.

3. C-ESR-F-00012, "F-Canyon and Outside Facilities Low Level Waste Characterization Plan", C. O. Jones, Nov. 27, 2001, Rev. No. 2.

4. NMM-PRG-2001-0793, F-Canyon/FB-Line Facilities Purex Operations Suspension Plan”, S. A. Williams, Feb. 2002, Rev. 0.

5. V-PMP-F-00010, "F-Canyon Complex Deactivation Project Plan", S. A. Williams, July, 2003, Rev. 2.

6. V-PMP-F-00011, "F-Canyon Complex Deactivation End Points Document", B. L. Anderson, March, 2003, Rev. 1.

7. Email dated Feb. 17, 2004, from Jacob Nims to Steve Wilson, "F Canyon Waste Characterization". 